\title{
PENELITIAN
}

\section{PERSEPSI PASIEN DENGAN HIV/AIDS DAN KELUARGANYA TENTANG HIV/AIDS DAN STIGMA MASYARAKAT TERHADAP PASIEN HIV/AIDS*}

\author{
Agung Waluyo**, Elly Nurachmah**, dan Rosakawati***
}

\begin{abstract}
Abstrak
Tujuan penelitian ini adalah mengidentifikasi persepsi pasien HIV/AIDS dan keluarganya tentang HIV/AIDS dan stigma masyarakat terhadap pasien HIV/AIDS. Pendekatan yang digunakan pada penelitian kualitatif ini adalah fenomenologi. Sejumlah 13 informan (7 pasien dan 6 anggota keluarga) berpartisipasi dalam penelitian ini. Profil demografik informan klien HIV/AIDS meliputi pendidikan sekolah menengah atas sampai perguruan tinggi, berjenis kelamin pria usia 18-40 tahun. Informan keluarga umumnya adalah kakak kandung (berjenis kelamin pria dan wanita) dan orangtua (ibu) dari klien HIV/AIDS berusia 45-55 tahun. Hasil analisis didapatkan beberapa tema: (1) Pengetahuan pasien/keluarga tentang HIV/AIDS yang rendah (2) Pasien tidak terinformasi tentang penyakitnya (3) Kepercayaan yang salah tentang HIV/AIDS dan cara penularannya (4) Pasien HIV/AIDS bertanggung jawab atas dan pantas untuk terinfeksi HIV/AIDS (5) Perasaan takut dikucilkan/ upaya untuk merahasiakan tentang penyakitnya (6) Perasaan tersisih/ dikucilkan oleh keluarga dan kelompok tertentu (7) Intimidasi/ teror fisik (8) Putus asa dan (9) Harapan pasien HIV/AIDS. Hasil penelitian ini dapat bermanfaat untuk meminimalkan stigma dengan cara mengoptimalkan pengetahuan masyarakat sehingga deteksi dini pada orang yang berisiko dapat dilakukan. Hal ini memungkinkan terjadinya optimalisasi terapi ARV dan efektifitas asuhan keperawatan pada pasien HIV/AIDS dan juga peningkatan kualitas hidup pasien.
\end{abstract}

Kata Kunci: keluarga, pasien HIV/AIDS, persepsi, stigma

\begin{abstract}
The purpose of this study was to identify the patient's and relative's perception on HIV/AIDS \& stigma amongst the people. The design of this qualitative research is phenomenology approach. Thirteen informants ( 7 patients and 6 relatives of the patients) participated the study. The demographic profile of the informants were male and female with age from 18 years old to 40 years old for the patient and 45-55 for relatives. The findings identified some themes which are: (1) Lack of knowledge about HIV/AIDS on patient and relatives (2) The patients were not well informed on their condition (3) Misperception on HIV/AIDS and mode of spreading of HIV/AIDS (4) HIV/AIDS patients are responsibled and deserved for having infected HIV/ AIDS (5) The effort of the patient \& their relatives to say nothing about their condition because they are afraid to be isolated from the community (6) The feeling of being isolated by the family member or a certain group of the people (7) Intimidation and physical Teror (8) The feeling of desperate and (9) Patient's hopes. The result of these studies could be beneficial to minimize stigma by improving the knowledge of the people where it may optimize the early detection on the high risk people. It could also optimizes the treatment of ARV \& the nursing care to the HIVIAIDS patient and their quality of life during AIDS stage.
\end{abstract}

Key words: Patient HIV/AIDS, Perception, Relatives, Stigma

\section{LATAR BELAKANG}

Kasus HIV/AIDS di Indonesia terus bertambah, hal ini dapat dilihat dari statistik kasus HIV/AIDS di Indonesia yang merupakan laporan resmi dari P2MPLP menyebutkan bahwa total kasus HIV/AIDS sampai Juni 2006 adalah 10859 (DEPKES, 2006) di mana pada tahun 2003 kasus yang dilaporkan di Pelita Ilmu masih berkisar 4159 orang. Jenis penyebaran HIV/ AIDS yang semula banyak diakibatkan oleh hubungan seksual bebas, lima tahun belakangan ini berubah menjadi penularan melalui jarum suntik pada pengguna NARKOBA (Media Indonesia, 2006). 
Meningkatnya jumlah penderitaHIV/AIDS saat ini menunjukkan belum optimalnya pemberian pendidikan kesehatan kepada masyarakat tentang HIV/AIDS. Kondisi inimembuktikan buruknyatingkat pengetahuan masyarakat terhadap HIV/AIDS (Riono \& Jazant, 2004).

Pemahaman yang kurang tepat tentang HIV/AIDS di masyarakat perlu diminimalkanagar penangananHIV/AIDS bukan dengan cara memerangi pasien HIV/AIDS tetapi memerangiterjadinya cara penyebaran penularan virus HIV. Dengan demikian fokus penanggulangannya ditujukan pada upaya preventif/ pencegahan. Upaya ini harus didukung dengan pengetahuan, sikap, dan perilaku masyarakat termasuk keluarga pasien yang menunjang tindakan pencegahan tersebut. Kondisiinidiperlukan terutama ketika merawat pasien dan mendampingi pasien selama perawatan berlangsung. Namun, sepertiyang dikemukakanolehHerek \& Capitanio (1993) bahwa pengetahuan dan pandangan masyarakat sering menjadikendala pemberian dukungan pada pasien karena pengetahuan yang salah.

Pengetahuanyang salah bukan satu-satunya faktor yang dapat mengakibatkan kurangnya perhatian masyarakat terhadap penanganan pasien HIV/AIDS, akan tetapi juga dimungkinkan karena adanya faktor lain sebagai dampak daripengetahuan yang kurang yaitu stigma yang pertama kali ditemukan di masyarakat Amerika. Stigma ini diasumsikan dapat terjadi di bagian belahan dunia manapun (Herek, et.al., 2002). Penelitian ini akan mengidentifikasi stigma terhadap pasien HIV/AIDS terutama yang terjadi di Indonesia khususnya yang dirasakan oleh pasien dan keluargadilingkungannya.

\section{METODOLOGI}

Tujuan penelitian ini adalah mengidentifikasi persepsi pasien HIV/AIDS \& keluarganya tentang HIV/AIDS dan stigma masyarakat terhadap pasien HIV/AIDS. Desain penelitianini adalahkualitatifeksplorasi, dengan pendekatan fenomenologi. Pendekatanfenomenologi memungkinkan peneliti melakukan eksplorasi secara mendalam pada pasien HIV/AIDS dan keluarganya, serta bagaimana mereka menyampaikan persepsi dan pengalamannya tentang stigma masyarakat (Stephenson \& Corben, 1997).

Penelitian ini dilakukan pada keluarga dan pasien denganHIV/AIDS yang sedang dirawat maupun rawat jalan di salah satu rumah sakit diJakarta. Sampelyang digunakan adalah enamkeluarga dan tujuh pasien yang telah dinyatakan positifHIV dari pemeriksaanELISA. Kriteria sampel adalah dapat berbahasa Indonesia, dan sampelkeluarga merupakan anggota keluarga pasien yang terdekat (ayah, ibu, anak, maupun saudara-saudara kandung pasien) yang secara aktif menjadi bagian darisistem pendukung pasien.

Wawancara dan observasi ini dilakukan selama 60 90 menit, dan beberapa informasi dilakukan dua kali wawancara dengan tujuan untuk memperdalam dan memverifikasi informasi. Kegiatan pengumpulan data dilakukan selama 12 minggu pada Juni-Agustus 2004.

\section{HASIL}

Informan klien HIV/AIDS berpendidikan sekolah menengah atas sampai perguruan tinggi, berjeniskelamin pria dengan usia 18-40 tahun. Informan keluarga umumnya adalah kakak kandung (berjenis kelamin pria dan wanita) dan orangtua (ibu) dari klien HIV/AIDS dengan usia 45 55 tahun.

Tema-tema yang munculpada persepsiklienHIV/AIDS dan keluarganya terhadapHIV/AIDS dan stigma didapatkan melalui content analysis. Hasilnya meliputi 9 tema yang ditampilkan dalam P1-P7 yang memiliki arti pasien ke-1 sampai ke-7 dan K1-K6 yang berartikeluargake-1 sampai ke-6.

\section{- Pengetahuan pasien/keluarga tentang HIV/AIDS yang rendah}

Hal yang tidak tepat tentang HIV/AIDS disampaikan olehtiga informan:

"Penyakit AIDS adalah penyakit yang disebabkan olehbakteri, kuman, virus"(P7)

"Nggak tahu, nggak tahu sama sekali..... apa itu penyakit AIDS, tapi katanya sih nggak bisa punya anak......"(P5)

Penyakit yang diawali dengan panas tinggi......kayak Tipus (K8)

Beberapa pasien maupun keluarga memiliki pengetahuan yang cukup baik tentang HIV/AIDS, seperti yang dituturkan oleh P1:

"Penyakit AIDS adalah penyakit penurunan daya tahan tubuh yang berbahaya, penyakit yang tidak bisa diobatin. Penyakit yang dapat mengakibatkan kematian.” (P1) 
Tidak hanya mereka (responden) memberikan pendapatnya tentang HIV/AIDS yang mereka ketahui, namun juga mereka memberikan pendapatnya tentang pengetahuan masyarakat akan HIV/AIDS:

"Mereka (masyarakat red.) menjauhi orang HIV/ AIDS karena pandangan dan pengetahuannya sempit. Walaupun sekarang diTV sudah banyak acara yang menampilkan sosok orang HIV/ AIDS.....yang diwawancara...."(P7)

\section{- Pasien tidak terinformasi tentang penyakitnya}

Ada sebagian pasien yang tidak jelas mendapatkan informasi yang menyatakan dirinya terinfeksi HIV. Seperti yang dituturkan oleh pasien:

"Saya nggak kenapenyakit ini(HIV/AIDS), Saya cuma sakit di dalem, di tenggorokan, sakit sariawan.....'(P1)

"Penyakit apa tuh..... saya nggak kena AIDS kok..."(P2)

"Saya masuk dirawat disini karena sakit paruparu, buang-buang air...”(P9)

Ada hal yang teridentifikasi saat wawancara berlangsung, yaitu pasien yang mendapatkan biaya perawatan dan pengobatan gratis, cenderung membuat pasien dan keluarga pasrah dan tidak aktif untuk terlibat didalam proses perawatan pasien.

"Wah saya dan keluarga nggak tahu. Mungkin karena kita kan pakai fasilitas GAKIN (kartu keluarga miskin) jadi pemeriksaan-pemeriksaan (\& hasilnya) kita nggak tahu...... kita nggak pernah dikasih tahu" (K4)

\section{- Kepercayaan yang salah tentang HIV/AIDS dan} cara penularannya

Kepercayaan yang dimiliki oleh pasien HIV/AIDS dan keluarga kemungkinan berhubungan dengan pengetahuan yang mereka miliki, seperti yang diutarakan oleh pasien:

"Penyakit yang tidak bisa disembuhkan, sangat menular, penyakit yang paling buruk, pokoknya hancur deh......."(P5)

Namun tidak semua kepercayaan pasien dan keluarga pasien berhubungan langsung dengan pengetahuan yang mereka miliki. Kepercayaan mereka lebih pada suatu kondisi penyakit yang diderita oleh pasien sebagai suatu hukuman Tuhan. Secara tidak langsung, apa yang mereka sampaikan menunjukkan adanya penurunan kekuatan dan ketahanan psikologis pasien dan keluarga saat menghadapi permasalahan saat pasien dirawat.

"Saya kaget sekali dan tidak menyangka kalau dia bisa kena........ (menangis)

Saya sampai berfikir kenapa ini terjadi, apa dosa kami kasihanilah kami ya Tuhan (menangis)" (K12)

Sampai suami saya, ayahnya dia bilang "Ya Tuhan dosa apa kami sehingga kami diberi hukuman begini berat....?" (K10) "Ya......, saya anggap ini (penyakit HIV/AIDS red.) hukuman Tuhan.......(menangis)

Hukuman Tuhan yang pantas aku terima.................." (P6)

Satu dari responden yang diwawancara pun menilai bahwa banyak masyarakat mempercayai hal yang salah tentang HIV/AIDS. Mereka memberikan pendapatnya tentang pengetahuan masyarakat akan HIV/AIDS:

"Masyarakat akan memandang orang AIDS sebagai orang yang perlu dihindari.......penyakit yang menyeramkan......orang AIDS perlu dijauhi supaya tidak tertular" (K3) .

\section{- Pasien HIV/AIDS bertanggung jawab atas dan} pantas untuk terinfeksi HIV/AIDS

Ada respon pasien dan keluarga yang menunjukkan bahwa masyarakat seakan-akan memiliki pendapat bahwa orang dengan HIV/AIDS memang layak terinfeksi HIV karena perilaku yang melatarbelakangi pasien terkena HIV/AIDS:

"Saya khawatir dengan pandangan masyarakat yang masih negatif dan mempersalahkan orang HIV/AIDS.........."

"Mengapa saya berpendapat seperti ini, karena saya sebelumnya pun, sebelum ada anggota keluarga yang sakit AIDS, saya menganggap seperti itu." (K3) 
Hal lain yang terjaring saat wawancara adalah pasien yang telah diberikan "label" oleh masyarakat bahwa mereka layak terinfeksiHIV/AIDS pun mulaiberfikir bahwa "label" tersebut memang harus diterima oleh pasien HIV/AIDS.

"Nggak tahu ya..... tapi kayaknya masyarakat pikir bahwa orang seperti kita (Gay) udah pantas kalau terkenaHIV/AIDS........"(P6)

„Kebanyakan masyarakat takut, masih sempit pemikirannya, mengucilkan orang-orang dengan HIV/AIDS. Kita harus terima bahwa masyarakat menjauhi pasien HIV/AIDS...."(P7)

- Perasaan takut dikucilkan/ Upaya untuk merahasiakan tentang penyakitnya

Beberapa pasien dankeluarga merasa bahwa kondisi penyakit yang dideritanya atau diderita oleh anggota keluarganya perlu untuk dirahasiakan. Hal ini cukup beralasan mengingat bahwa pasien dan keluarga memiliki lingkungan masyarakat yang mungkin belum mudah untuk menerima kondisi seseorang yang menderita HIV/AIDS. Salah satu responden yaitu keluarga pasien (ibu kandung) merasa tidak diberi tahu oleh anaknya bahwa dirinya telah menderita HIV positif. Ibu daripasien ini menyampaikan bagaimana dia, pada akhirnya, mengetahui bahwa anaknya terkena HIV positif.

"Bulan Juni....tapi dia enggak langsung kasih tahu.....tapi saya curiga.....mungkin dia nggak ngasih tahu karena takut diasingkan oleh saudarasaudara......"(K3)

Setelah ibu dari anak yang menderita HIV ini mengetahuibahwa anaknya positif, dia pun kemudian melakukan hal yang sama seperti anaknya, di mana ia ikut merahasiakan kondisi ini kepada orang banyak.

"Saya takut lingkungan tempat kerja saya mengucilkan saya, menyalahkan saya tidak bisa mendidik anak......saya ini guru....guru agama..........(menangis)...........

Saya khawatir dengan pandangan masyarakat yang masih negatif dan mempersalahkan orang HIV/AIDS " (K3)

Selain asumsi anggota keluarga (ibu kandung) pasien yang menyatakan bahwa lingkungan masyarakat dirasa masih sulit untuk menerima orang dengan HIV/ AIDS, P5 pun memiliki anggapan yang sama.

"Masyarakat pasti ngejauhin kita........ pasti

mereka ngeringeliat kita dan berusaha mengucilkan kita...."(P5)

Senada dengan ungkapan yang disampaikan oleh P5, anggota keluarga lain pun menekankan bahwa sangat berisiko untuk dikucilkan apabila dirinya mencoba terbuka tentang kondisi penyakit yang diderita oleh anggota keluarganya.

"Mereka biasanya menjauhiorang-orang HIV dan keluarganya.... Karena mereka berfikir bahwa penyakit HIV/AIDS itu penyakit yang sangat ditakuti, sangat menular dan sangat mematikan. Jadi saya tidak cerita orang-orang, karena saya takut mereka mengucilkan kita.......termasuk keluarga-keluarga yang lain, saya tidak cerita....... Saya takut mereka ngomongin kita macammacam dan menjauhi kita......." (K13)

\section{- Perasaan tersisih/ dikucilkan oleh keluarga dan kelompok tertentu}

Selain perasaan takut dikucilkan, ada beberapa pasien yang memang oleh lingkungannya, keluarga atau kelompok tertentu, dikucilkan karena dirinya diketahui telah mengidap HIV positif.

'Dan kebanyakan salah pengertian (persepsi red.) sehingga mereka mengucilkan orang HIV/AIDS, termasuk anggota keluarga saya sendiri ada yang mengucilkan saya......." (mata berkacakaca).........(P2)

Tidak seperti pasien 2 yang dikucilkan oleh anggota keluarganya karena HIV positifnya, salah satu pasien telah diperlakukan berbeda oleh anggota keluarganya sejak kecil, jauh sebelum dirinya mengidap HIV/ AIDS. Perlakuan seperti ini dimungkinkan karena pasien secara fisik terlahir sebagai lelaki namun dia merasa dirinya lebih cocok apabila menjadi seorang perempuan.

Mamak saya bilang "kok dia kayak perempuan ya....". Saat itu saya mendengarnya secara tidak sengaja, ketika akan masuk ke kamar ibu saya. Saya hanya bisa sedih, "Ya Tuhan kenapa dengan diri saya.." "Ya Tuhan mengapa orang tua saya mengatakan hal seperti itu?' 
"Mengapa dia tidak bisa menerima saya apa adanya?" Saya hanya bisa pasrah, dan karena lingkungan tidak bisa menerima saya, saya pindah ke Jakarta........ (menangis).........(P6)

Kelompok tertentu yang memang berisiko tinggiuntuk mengidap HIV/AIDS, seperti waria, sebelummereka pada akhirnya mengidap penyakit tersebut, mereka sudah dikucilkan. Hal ini yang sering membuat mereka enggan untuk memeriksakan diri ke pelayanan kesehatan berkenaan dengan risiko HIV/AIDS yang mungkin dideritanya.

Waria-waria yang sadar mau memeriksakan darah, kadang mereka sering dikucilkan, Jangan menjauhi waria-waria... kasihan mereka... mereka sudah cukup menderita (P6)

Beberapa pasien dan keluarga merasa bahwa pengucilan tidak hanya dilakukan oleh orang awam, namun ditengarai juga dilakukan oleh tim kesehatan maupun tempat pelayanan kesehatan (rumah sakit) tertentu.

"Saya awalnya tidak tahu, setelah saya periksa darah di RS H(RS Swasta Besardi Jakarta Barat) katanya saya disuruh ke sini, di sana untuk merawat penyakit ini (HIV/AIDS) tidak ada alatnya.....Jadi saat hasil darahnya ada, dokter di RS tersebut langsung telpon ke dokter disini untuk segera dirujuk.......

Saya sedih kenapa saya harus pindah...."(P7)

"sebelumnya anak saya ini dirawat diRS di Jakarta Timur, trus sehat pulang. Udahmau makan banyak waktu itu. Beberapa minggu sakit, masuk RS Swasta di Jakarta selatan, baru masuk dokternya sudah menyarankan saya untuk pindah ke RS ini..."(K13)

\section{- Intimidasi/ teror fisik}

Walaupun tidak secara spesifik disampaikan, beberapa pasien mengalami intimidasi dan teror fisik terhadap kondisi mereka yang telah mengidap HIV/ AIDS.

Jelek sekali, mereka (masyarakat) itu nyumpahin, mengucilkan

Temen saya ada yang setelah diperiksa dan ketahuan HIV, dia dipukulin, dikucilkan dan diusir..." (P2)
Intimidasi terutama pada golongan tertentu yang diketahuimemilikirisiko tinggiuntuk mengidap HIV/ AIDS, dalam hal ini kelompok waria.

Saya juga sering dilecehkan dengan ke"waria"an saya dengan ngeledek "He, bencong, bencong.....!" (P6)

"Anggota keluarga saya sendiri ada yang mengucilkan saya (mata berkaca-kaca).

\section{- Putus asa}

Perasaan putus asa dan hilangnya harapan pada pasien dengan HIV/AIDS dimulai sejak pencarian upaya untuk menyembuhkan penyakitnya dan meminimalkan keluhan yang dideritanya.

Padahal udah coba berobat ke mana-mana. Awalnya dia buang-buang air, terus berobat. Tapi nggak sembuh-sembuh. Saya sedih luar biasa.....sampai nyaris putus asa.(K 13)

Adanya respon masyarakat untuk mengucilkan pasien HIV/AIDS maka perasaan putus asa dan hilangnya harapan yang dialami oleh pasien dengan HIV/AIDS semakin meningkat seiring bertambahnya keluhan yang dialaminya.

Tapi karena dikucilkan jadi menurun semangat untuk hidupnya, jadiputus asa........mereka akan menganggap buat apa lagi saya hidup.....sehingga tidak sedikit yang putus asa......(K3)

Perasaan gue hancur, berantakan gila !! gue kena AIDS?.........(menangis).......(P11).

\section{- Harapan pasien HIV/AIIDS}

Pasien dan keluarga secara tidak sengaja memiliki harapan-harapan yang disampaikan berkenaan dengan kondisi mereka dan juga keluarganya. Harapan pasien dan keluarga berkisar pada respon masyarakat yang kurang mendukung. Mereka berharap agar mereka dapat lebih diterima di lingkungan masyarakat.

Jangan dong,.....kita ini manusia juga..........(menangis).........jangan kita dijauhi.

Kita hidup nggak bisa sendiri........kita saling membutuhkan....................(P11). 
Mereka harusnya tidak seperti itu, orang HIV/ AIDS harusnya dirangkul, diberi dukungan..... Harusnya orang HIV/AIDS jangan dibuang begitu aja.....(K10)

Ada pula anggota keluarga yang menyampaikan bahwa dengan kurang diterimanya pasien HIV/AIDS di tengah-tengah masyarakat, membuat mereka (pasien HIV/AIDS) tidak terbuka. Oleh karena itu mereka berharap sebelum keadaan pasien HIV/AIDS semakin lanjut, mereka bisa dapat lebih diterima oleh masyarakat.

Ya kasihan sama pasiennya, mereka butuh dukungan. Kebanyakan pasien HIV/AIDS tidak terbuka, kenapa karena lingkungan tidak mau menerima orang dengan penyakit HIV/AIDS. Kalau mereka tidak terbuka, makin lanjut kondisinya makin sulit keadaannya (K8).

\section{PEMBAHASAN}

Tema-tema yang ditemukan dari penelitian ini adalah pengetahuan pasien/ keluarga tentang HIV/AIDS yang rendah, kepercayaan yang salah tentang HIV/AIDS dan cara penularannya, orang HIV/AIDS bertanggung jawab atas dan pantas untuk terinfeksi HIV/AIDS. Tema lain yang teridentifilasiadalah pasien tidak terinformasitentang penyakitnya, perasaan takut dikucilkan/ upaya untuk merahasiakan tentang penyakitnya, perasaan tersisih/ dikucilkan oleh keluarga dan kelompok tertentu, intimidasi/ teror fisik, putus asa dan harapan pasien HIV/AIDS.

Pengetahuan pasien/ keluarga tentang HIV/AIDS yang rendah memang tidak ditemukan pada semua responden. Namun pengetahuan dan pemahaman masyarakat yang rendah harus menjadi perhatian utama dari perawat dan tenaga kesehatan yang lain karena hal ini akan memicu munculnya stigma di lingkungan pasien yang paling kecil, yaitu keluarga. Penyebab dari rendahnya pemahaman pasien dan keluarganya tentang HIV/AIDS dapat disebabkan karena masih tingginya ketidaktahuan pasien terhadap prognosa yang akan mereka alami seperti yang telah disampaikan pada penelitian Herek dan Capitanio (1993) yang menunjukkan bahwa rendahnya pemahaman masyarakat tentang HIV/AIDS mungkin disebabkan olehrendahnya rasa percaya masyarakat akan informasi mengenaiHIV/AIDS dan prognosanya.
Pasien dan keluarga yang memiliki informasi dengan baik dan jelas tentang HIV/AIDS bukan hanya dapat meminimalkan terjadinya stigma pada pasien HIV/AIDS, tetapi juga akan mengoptimalkan deteksi dini pada anggota keluarga maupunorang di sekitarnya. Semakin dini deteksi, semakin baik hasil dari terapi pada pasien HIV positif. Hal ini senada dengan apa yang disampaikan oleh Herek (1990) bahwa pengetahuan dapat meningkatkan perubahan perilaku berisiko tinggi HIV/AIDS dan juga dapat meminimalkan transmisiHIV itu sendiri.

Herek (1990) menyebutkan bahwa sebagian masyarakat Amerika memiliki anggapan bahwa penderita HIV/AIDS bertanggung jawab atas dan pantas untuk terinfeksi HIV/AIDS. Hal ini pun terjadi pada studi ini. Selain itu pengaruh budaya, sosial, dan proses psikologi pada suatu penyakit bisa memberi dampak terhadap munculnya stigma. Situasi inijuga terjadipada individu yang mengidap HIV/AIDS, di mana umumnya stigma yang muncul adalah stigma yang berupa perilaku tidak "mengenakkan" pada individu tertentu.

Selain perilaku, pemahaman dan kepercayaan seseorang pun dapat mempengaruhi terjadinya stigma pada diri seseorang terhadap pasien/ orang yang menderita HIV/ AIDS. Sikap-sikap tersebut menunjukkan adanya suatu proses gabungan antara terbentuknya proses psikologis seseorang dan pengaruh budaya yang berkembang di suatu daerah (Herek, 1990).

Studi yang dilakukan oleh Herek (1990), contoh yang disampaikan untuk menunjukkan adanya stigma pada orang dengan HIV/AIDS adalah apabila seseorang berfikir bahwa HIV/AIDS merupakan penyakit yang sangat berbahaya apabila tertular. Kemudian, budaya dimana ia tinggal menganggap bahwa yang paling rentan dan mungkin terinfeksi adalah kalangan Gay (homo). Itulah sebabnya individu tersebut akan berfikir bahwa hal yang paling tepat untuk menghindari dirinya dari tertularnya dengan HIV/AIDS adalah dengan cara memerangi dan memusuhi kelompok Gay.

Studi ini memang tidak secara eksplisit terlihat adanya tindakan memusuhi dari masyarakat terhadap kelompok tertentu. Namun, dari apa yang diuraikan oleh pasien (P6), berdasarkan riwayat dan pengalaman hidupnya dapat disimpulkan bahwa dirinya dan kelompoknya (gay dan waria) mengalami hal yang kurang 
lebih sama seperti apa yang dicontohkan oleh Herek. Masyarakat memandang bahwa kelompok gay atau waria yang memang berperilaku berisiko untuk tertularnya HIV perlu untuk dihindari, seperti dirimereka menghindari dari HIV/AIDS.

Selain ketidakpedulian masyarakat terhadap kondisi pasienHIV/AIDS, hal lain yang penting untuk diperhatikan adalah bahwa dengan ketidak tahuan pasien, keluarga dan orang-orang di sekitarnya, membuat test HIV yang harus secara dini dilakukan oleh pasien maupun orang-orang di sekitar pasien yang berisiko tidak dapat dilakukan dengan segera. Dengandemikian, deteksi dini pada orang berisiko HIV/AIDS tidak dapat dilakukan (Chesney \& Smith, 1999). Yang kemudian berdampak pula pada tidak optimalnya terapi anti retro viral (ARV) yang diberikan pada pasien HIV/AIDS.

Masalah lain yang muncul adalah adanya perasaan takut dikucilkan dan upaya untuk merahasiakan tentang penyakitnya. Perasaan ini sangat berkaitan dengan respon yang diterimanya tentang masyarakat yang cenderung untuk mengucilkan pasien dan keluarganya. Perasaan takut dikucilkan ini dimiliki oleh P5 dan K3 yang menyatakan bahwa mereka berupaya merahasiakan status kesehatan dirinya dan anggota keluarganya karena ingin mempertahankan hubungan sosial dengan lingkungannya.

Studi lanjutan yang dilakukan oleh peneliti yang sama (Herek, 1999) menunjukkan stigma yang terjadi di masyarakat Amerika dikarenakan adanya kecurigaan yang berlebihan dan perasaan permusuhan kepada kelompok tertentu ( gay dan biseksual) yang mereka anggap sebagai kelompok yang bertanggung jawab terjadinya peningkatan jumlah penderita HIV/AIDS. Para penderita HIV/AIDS pun dikucilkan dari lingkungannya, dan mereka dipersalahkan dengan kondisiHIV/AIDS yang dideritanya (Herek et.al., 2002). Senada dengan apa yang disampaikan oleh Herek, pasien dengan orientasi seksual sejenis pun pada studi ini mendapatkan perlakuan yang hampir sama seperti yang dialami oleh kaum gay di Amerika.

Proses pengucilan terhadap kelompok tertentu yang beriiko HIV/AIDS tidak hanya dilakukan oleh masyarakat awam, tetapi juga oleh kelompok profesi tertentu dimana sepatutnya memberikan asuhan dan perlindungan pada pasien dengan HIV/AIDS. Kelompok dimaksud adalah tim kesehatan di rumah sakit, seperti yang disampaikan oleh beberapa keluarga pasien pada studi ini.

Kondisi ini pun dilaporkan oleh Fredriksson dan Canabus (2004) di mana ada sekelompok pasien yang merasa distigma dan dimusuhi oleh tim kesehatan karena HIV/AIDS nya. Dampaknya adalah banyak pasien yang tidak mendapatkan terapi dengan baik dan terus menerus karena malas untuk datang ke rumah sakit. Padahal keberhasilan proses perawatan dan pengobatan sangat dipengaruhi keteraturan pasien datang ke rumah sakit untuk memeriksakan diri dan mendapat pengobatan. Sebaliknya, keteraturan kehadiran pasien sangat dipengaruhi oleh penerimaan pihak rumah sakit terutama daritim kesehatan terhadap pasien HIV/AIDS dan keluarganya.

Pengucilan pasien HIV/AIDS tidak hanya terjadi oleh lingkungan atau masyarakat luas, tetapi sebaliknya sebagian pasien justru memilikimasalah di lingkungan keluarganya sendiri, seperti yang terungkap dari percakapan pasien 6 dan keluarga 3. Pengalaman ini juga dialami oleh responden pada penelitian yang dilakukan oleh Fredriksson dan Canabus (2004).

Terjadinya pengucilan olehanggota keluarganya sendiri dimungkinkan terjadi akibat minimnya informasi yang didapat oleh pasien dan anggota keluarganya. Dengan demikian menjadijelas di sini, bahwa kurangnya informasi tentang HIV/AIDS dapat menimbulkan serangkaian masalah yang justru dapat memperberat kondisi yang dialami pasien dan keluarganya.

Herek dan Glunt (1991) melanjutkan kegiatannya dengan melakukan penelitian yang mengidentifikasi bagaimana masyarakat Amerika melihat dan menilai kasus HIV/AIDS. Hasil dari penelitian awal ini cukup mengejutkan dimana opini masyarakat Amerika tentang HIV/AIDS yang memandang penderita HIV/AIDS harus di kucilkan dan diintimidasi agar dapat di pisahkan dari kehidupan "normal". Kelompok ini pun mempersalahkan mereka yang menderita HIV/AIDS, mengapa mereka sampaitertular HIV/AIDS.

Hasil yang didapat oleh Herek dan Glunt ini sejalan dengan apa yang terdapat pada studi ini bahwa intimidasi dan pemisahan diri pun terjadi pada orang-orang yang 
berperilaku berisiko HIV/AIDS. Mereka yang dianggap berisiko seperti kelompok gay dan waria, dikucilkan oleh sebagian masyarakat karena lingkungan menganggap mereka "berbeda" atau juga karena mereka dipersalahkan karena perilaku mereka berisiko terhadap penyebaran HIV/AIDS. Vlahov (1998) menambahkan bahwa umumnya sebagian kasus intimidasi juga sejalan dengan masalah-masalah klasik yang lain seperti kemiskinan, peredaran obat-obatan narkoba dan lainnya, sehingga kondisi ini memperberat penanganan dan pencegahan HIV/ AIDS dilingkungan yang berisiko tadi.

Dari kondisi yang mereka alami, tidak sedikit orang dengan HIV/AIDS ataupun yang berisiko HIV/AIDS mengalami putus asa. Dengan keputusasaannya, pasien dan keluarga semakin terisolasi dari jangkauan pelayanan kesehatan baik dalam pencegahan maupun penanganan kondisi HIV/AIDS. Dan bukan hal yang tidak mungkin bahwa jumlah penderita HIV/AIDS dapat cenderung meningkat karena keterisolasian pasien dari lingkungan dan informasi.

Studi yang dilakukan oleh Herek dan Capitanio (1993) menunjukkan bahwa pemberian informasi saja tidaklah cukup untuk meminimalkan stigma yang terjadi di masyarakat. Stigma pada pasien HIV/AIDS diketahui memiliki dampak yang cukup serius terhadap upaya masyarakat meminimalkan penyebaran HIV/AIDS terutama padakalangan atau kelompok yang berisiko tinggi pada terjadinya penyebaran HIV/AIDS.

Tidak hanya dinegara maju sepertiAmerika, dinegara sedang berkembang seperti Bangladesh, perlakuan masyarakat dalam memberikan stigma pada pasien HIV/ AIDS kurang lebih sama. Stigma yang terjadi diBangladesh berupa pendapat masyarakat yang menyatakan bahwa penderita HIV/AIDS seharusnya tidak diijinkan untuk bekerja agar dapat menghindari penyebaran penyakit HIV/ AIDS tersebut (Islamet.al., 2002). Dengandemikian dapat dilihat bahwa stigma merupakan masalah yang terjadi dimana-mana, dan tidak hanya terjadi padanegara dengan latar belakang budaya, sosial, dan agama tertentu. Untuk itu, upayauntuk meminimalkan stigma harus menjadimoral force sehingga kondisi ini mampu untuk mendukung tercapainya penurunan angka HIV/AIDS.

\section{KESIMPULAN}

Ada dua hal yang diperoleh dari studi ini yaitu pertama, stigma merupakan masalah yang terjadi di mana-mana, dan tidak hanya terjadi pada negara dengan latar belakang budaya, sosial, dan agama tertentu. Kedua, diketahui ada indikasi yang menunjukkan bahwa pengetahuan dan pemahaman tentang HIV/AIDS masyarakat rendah. Kedua hal ini saling berkaitan karena rendahnya pengetahuan masyarakat tentang HIV/AIDS akan memicu munculnya stigma. Dampak lain yang akan terjadi adalah pasien yang mengalami stigma cenderung tidak akan terinformasi dengan baik dan jelas tentang pencegahan, deteksi dini, dan pengangan HIV/AIDS nya dan anggota keluarga maupunorang di sekitarnya. Semakin dini deteksi, semakin baik hasil dari terapi pada pasien HIV positif.

Ketidaktahuan pasien, keluarga dan orang-orang di sekitar pasien HIV/AIDS, membuat test HIV yang harus secara dini dilakukan oleh pasien maupun orang-orang disekitar pasien yang berisiko tidak dapat dilakukan dengan segera. Deteksidini pada orang berisiko HIV/AIDS tidak dapat dilakukan dan dapat berdampak pada tidak optimalnya terapiARV yang diberikan pada pasien HIV/ AIDS. Sebenarnya, semakin dini deteksi dini HIV/AIDS semakin baik hasil yang akan didapat pada terapi ARV pasien HIV/AIDS.

Di sisi lain pemahaman dan kepercayaan seseorang, pun dapat mempengaruhi terjadinya stigma pada diri seseorang terhadap pasien/ orang yang menderita HIV/ AIDS. Sikap-sikap tersebut menunjukkan adanya suatu proses gabungan antara terbentuknya proses psikologis seseorang dan pengaruh budaya yang berkembang.

\section{* Dana Penelitian dari Peneliti Muda IV FIK-UI 2004}

** Agung Waluyo, S.Kp., M.Sc., Elly Nurachmah, DNSc: Staf Akedemik Fakultas Ilmu Keperawatan UI

*** Ns. Rosakawati, S.Kep.: Staf RSK Dharmais 


\section{KEPUSTAKAAN}

Chesney, M.A. \& Smith A.W. (1999). Critical delays in HIV testing and care: The potential role of stigma. Am Behav Scientist, 42(7):1162-74.

Culbert, G. \& Waluyo, A. (2003). Persepsi Mahasiswa S1 Keperawatan terhadap HIV/AIDS \& Pasien HIV/AIDS. Laporan hasil penelitian telah dipresentasikan melalui poster pada konferensi internasional keperawatan HIV-AIDS di Chiang Mai, 7-9 Juli 2004.

DEPKES (2006) Statistik kasus HIV/AIDS di Indonesia. Depkes RI: Ditjen P2M \& PL.

Fredriksson J. \& Canabus A. (2004) HIV/AIDS Stigma \& Discrimination: Attitudes towards $H I V \& A I D S$. (Edited by Jenni and Annabel). Philadelphia: Saunders.

Herek, G.M. \& Capitanio, J.P. (1993). Public reactions to AIDS in the United States: A second decade of stigma. American Journal of Public Health, 83 (4), 574-577.

Herek, G.M. \& Glunt, E.K. (1991). AIDS-related attitudes in the United States: A preliminary conceptualization. The Journal of Sex Research, 28 (1), 99-123.

Herek, G.M. (1990). Illness, stigma, and AIDS. In P. Costa \& G.R. VandenBos (Eds.). Psychological aspects of serious illness (pp. 103-150). Washington, DC: American Psychological Association.
Herek, G.M., Capitanio, J.P. \& Widaman, K.F. (2002). HIV-related stigma and knowledge in the United States: Prevalence and trends, 1991-1999. American Journal of Public Health, 92(3), 371-377.

Islam, M.T., Mostafa, G., Bhuiya, A.U., Hawkes, S., $\&$ de Francisco, A. (2002). Knowledge on, and attitude toward, HIV/AIDS among staff of an international organization in Bangladesh. Health Popul Nutr. Sep; 20(3): 271-8

Media Indonesia. (2006). Kasus HIV/AIDS di Indonesia, 12 Desember 2006, Litbang Media Group

Pelita Ilmu. (2003). Majalah yayasan pelita ilmu. April: 23, 24-25

Riono P. \& Jazant S., (2004) The current situation of the HIV/AIDS epidemic in Indonesia. AIDS education and prevention. 16(3), 78-90

Stephenson, N. \& Corben, V. (1997) Research mindedness for practice: An interactive approach for nursing and health care. London: Churchill Livingstone.

Thomas, B.S. (1990) Nursing research, an experiential approach. St. Louis: Mosby Company.

Vlahov D, et al. (1998) Violence among women with or at risk for HIV infection. AIDS Behav, 2(1): 53-60. 